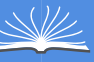

Global Journals In

(3)

\title{
Herbal Recipes, Drug Indications and Sustainability Potential of Traditional Oral Liquid Formulations in Ogbomoso, Nigeria
}

\author{
By Ogunkunle, A. T. J., Ideh, Jennifer E. \& Jimoh, M. A.
}

Abstract- Confirmation of identity, along with determination of the quality and purity of herbal drug is an important step towards ensuring its safety and efficacy. This study therefore sought to document the botanical constituents and drug indications of traditional oral liquid herbal formulations (TOLHFs) manufactured in Ogbomoso, Nigeria. It also examined the conservation status of the medicinal plants so used alongside the cultivation efforts being made by the drug manufacturers in order to provide information on whether continual exploitation of the plants for TOLHFs is sustainable. Through a questionnaire, 14 traditional herbal medical practitioners (THMPs) provided information on the recipes of their products, the sources of their raw material herbs, and types of health conditions treated or managed with the drugs. Sustainability potential of the drugs was quantified as relative percentage of the three choices of sources of raw material herbs available to the manufacturers in conjunction with the conservation status of the plant species as recorded by the International Union for Conservation of Nature (IUCN).Fifty- seven medicinal plant species (in 34 angiosperm families) were used to formulate 71 herbal recipes that are indicated for treating 14 different health conditions.

Keywords: medicinal plants; traditional oral liquid herbal formulations, sustainable exploitation of medicinal herbs; ethno-medicine; forest conservation; ethno-botany.

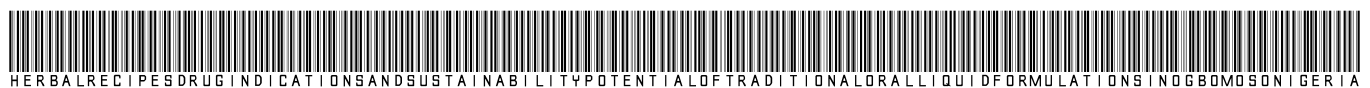

Strictly as per the compliance and regulations of:

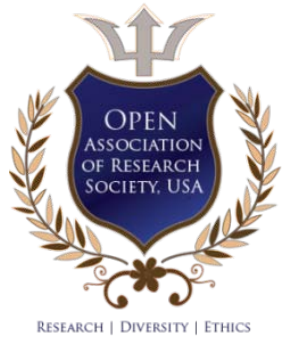

(C) 2021. Ogunkunle, A. T. J., Ideh, Jennifer E. \& Jimoh, M. A. This is a research/review paper, distributed under the terms of the Creative Commons Attribution-Noncommercial 3.0 Unported License http://creativecommons.org/licenses/by-nc/3.0/), permitting all non commercial use, distribution, and reproduction in any medium, provided the original work is properly cited. 


\title{
Herbal Recipes, Drug Indications and Sustainability Potential of Traditional Oral Liquid Formulations in Ogbomoso, Nigeria
}

\author{
Ogunkunle, A. T. J. ${ }^{\alpha}$, Ideh, Jennifer E. ${ }^{\sigma}$ \& Jimoh, M. A. ${ }^{\rho}$
}

Abstract- Confirmation of identity, along with determination of the quality and purity of herbal drug is an important step towards ensuring its safety and efficacy. This study therefore sought to document the botanical constituents and drug indications of traditional oral liquid herbal formulations (TOLHFs) manufactured in Ogbomoso, Nigeria. It also examined the conservation status of the medicinal plants so used alongside the cultivation efforts being made by the drug manufacturers in order to provide information on whether continual exploitation of the plants for TOLHFs is sustainable. Through a questionnaire, 14 traditional herbal medical practitioners (THMPs) provided information on the recipes of their products, the sources of their raw material herbs, and types of health conditions treated or managed with the drugs. Sustainability potential of the drugs was quantified as relative percentage of the three choices of sources of raw material herbs available to the manufacturers in conjunction with the conservation status of the plant species as recorded by the International Union for Conservation of Nature (IUCN). Fiftyseven medicinal plant species (in 34 angiosperm families) were used to formulate 71 herbal recipes that are indicated for treating 14 different health conditions. The sources of raw material herbs, in relative terms, were purchase from herbal markets/suppliers(38.7\%), collection from the wild vegetation $(35.5 \%)$ and cultivation of some of the herbs for use $(25.8 \%)$. The herbal material used included fruits, seeds, leaves, stem barks, flowers, roots and rhizomes, most of which can be sustainably harvested. Based on the IUCN records, only six (i.e. $10.5 \%$ ) of the 57 plant species have been evaluated and placedin the categories of 'Least Concern' (Ceiba pantandra, Cola acuminata, Ficus exasperata), 'Vulnerable' (Garcinia kola, Khaya senegalensis) and Endangered' (Jatropha curcas). Production of TOLHFs in Ogbomoso was therefore, adjudged to be sustainable with minimal potential injury on the natural flora. Medicinal plant cultivation by THMPs and herb vendors should however, be further encouraged or enforced.

Keywords: medicinal plants; traditional oral liquid herbal formulations, sustainable exploitation of medicinal herbs; ethno-medicine; forest conservation; ethno-botany.

\section{INTRODUCTION}

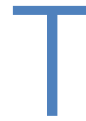
he traditional herbal medical practitioners (THMPS) in Ogbomoso, Nigeria produce and market various herbal preparations used for different types of ill health conditions. Among these are the traditional oral

Author a $\sigma \rho$ : Department of Pure and Applied Biology, Ladoke Akintola University of Technology, P.M.B. 4000, Ogbomoso, Oyo State, Nigeria. e-mail: tjogunkunle@lautech.edu.ng liquid herbal formulations (TOLHFs) used by the residents belonging to different socio-economic classes in the city (Ogunkunle and Ashiru, 2011). The efforts of the THMPs are commendable against the backdrop of rising cost of imported medication in Nigeria(High Commission of India in Nigeria, 2020), along with scarcity and cost of the commodities used in manufacturing drugs locally (Fatokun, 2020), and the fact that there are some areas in which orthodox medicine is known to be weak (Isola, 2013). However, herbal products from Africa have been called to question on account of adulteration, substitution, contamination, misidentification of ingredients, lack of standardisation, incorrect preparation and/or dosage, inappropriate labelling and/or advertisement (Lau et al., 2003; World Health Organization, 2003). For these reasons, herbal products from Africa have not enjoyed worldwide acceptability compared to those from other countries such as India and China (Patwardhan et al. 2005).

Quality of herbal medicines is defined by World Health Organisation (2002) on the basis of their reproducible efficacy and safety, while Bauer (1998) identifies quality criteria in terms of the scientific definition of the raw materials. Based on these definitions, standardisation and quality control of herbal formulations can be said to recline on their identity and purity. So, correct identification and quality assurance of the starting materials are essential prerequisites to ensuring reproducible quality of herbal medicine, which will in turn contribute to its safety and efficacy (Kadam et al., 2012). The belief in many quarters is that it is difficult to establish comprehensive quality for herbal formulations because of professional secrecy of THMPs. However, recent developments have shown that this challenge is surmountable (Obu, 2015). Considering the raw medicinal herbs for TOLHFs in Ogbomoso as 'active ingredients' for these drugs (World Health Organization, 2000), their enumeration formed the main purpose of this study.

There is substantial evidence to show increasing human dependence of herbal medicine for primary health care (World Health Organisation, 1998). It is however regrettable that users of herbal medicine seldom seek to know where the herbs they use come from. We should be mindful of the source of our 
medicinal herbs because these items are inextricably connected to the processes that produce them; and we cannot be healthy unless our environment is healthy. To these extent, if we choose to use plants as our medicine, we become responsible for ensuring that the vegetation or environment that produced the plants are safe and sustainable. These are the thoughts of the professionals advocating for sustainable herbal medicine (Pastogi and Kaphle, 2011; Pesic, 2015; Chen et al., 2016).

According to World Health Organisation (2003), and Chen et al. (2016), the strategies for ensuring sustainability of medicinal plants production include in situ and ex situ conservation efforts, controlled cultivation and sustainable harvesting, among others.

For these strategies to produce the desired effects in a country, the political will is a requirement. The government of Nigeria on 30 September, 1992 promulgated the Medical and Dental Practitioners' (Amendment) Decree number 78, which placed traditional and alternative medicine side by side with orthodox medicine (ABFR \& Co., 1996). This step is commendable, but not enough, until it is backed with pragmatic policies and programmes. Presently, there is no government policy in place to ensure sustainability of herbal medicine and the protection of environment in the country with particular reference to medicinal plants (Osunderu, 2009). Therefore, there is no information on whether continual exploitation of medicinal plants for TOLHFs in Ogbomoso is sustainable or not. Filling this gap was another area of focus in this study.

The objectives of this study were to botanically characterise the TOLHFs from Ogbomoso; to ethnomedicinally document their health indications; and to evaluate the sustainability status of the drugs in the study area based on the IUCN's conservation status of the medicinal plants alongside efforts on their cultivation made by the THMPs.

\section{Materials and Methods}

This study, which was conducted in 2014 covered the five local government areas (LGAs) of Ogbomoso land, Oyo State, Nigeria. The target population consisted of the THMPs in the study location who produced, marketed and provided healing services with TOLHFs. Initial selection of the participants was doneusing stratified sampling technique, with each of the LGAs taken as a stratum. Fourteen of the THMPs were eventually found suitable for inclusion, to whom a questionnaire was administered or used as an interview schedule (Figure 1).

Question items were developed for four different sections of the questionnaire to seek information on the various areas of focus of the study: socio-demographic and professional profiles of the THMPs, types and drug indications of the TOLHFs they produced, recipes and formulations of the drugs, and sources of the medicinal herbs used as raw materials (Figure1). In seeking information on the sources of the herbs, the THMPs were provided a list of possible sources namely purchase, collection from the wild, cultivation, etc. and each of them was asked to tick as many of the options as applicable to him or her. In analysing the data supplied, each of the multiple choices was considered as a separate variable across the 14 participants and counted. A summation of the three alternatives selected was obtained and equated to $100 \%$, from which the relative percentage of each choice was computed. The magnitude of the relative percentage obtained for cultivation of the required herbal materials was taken as sustainability index for the herbal liquid drugs in the study area.

The name of each of the 57 plant species used by TOLHF manufacturers was cross-checked against the red list of threatened plant species compiled by the International Union for Conservation of Nature (IUCN, 2017) to obtain information on its conservation status or population dynamics. The proportion of the plant species in the threatened category, taken alongside conservation efforts by the THMPs, was used to suggest whether manufacturing of TOLHFs in Ogbomoso was sustainable. 


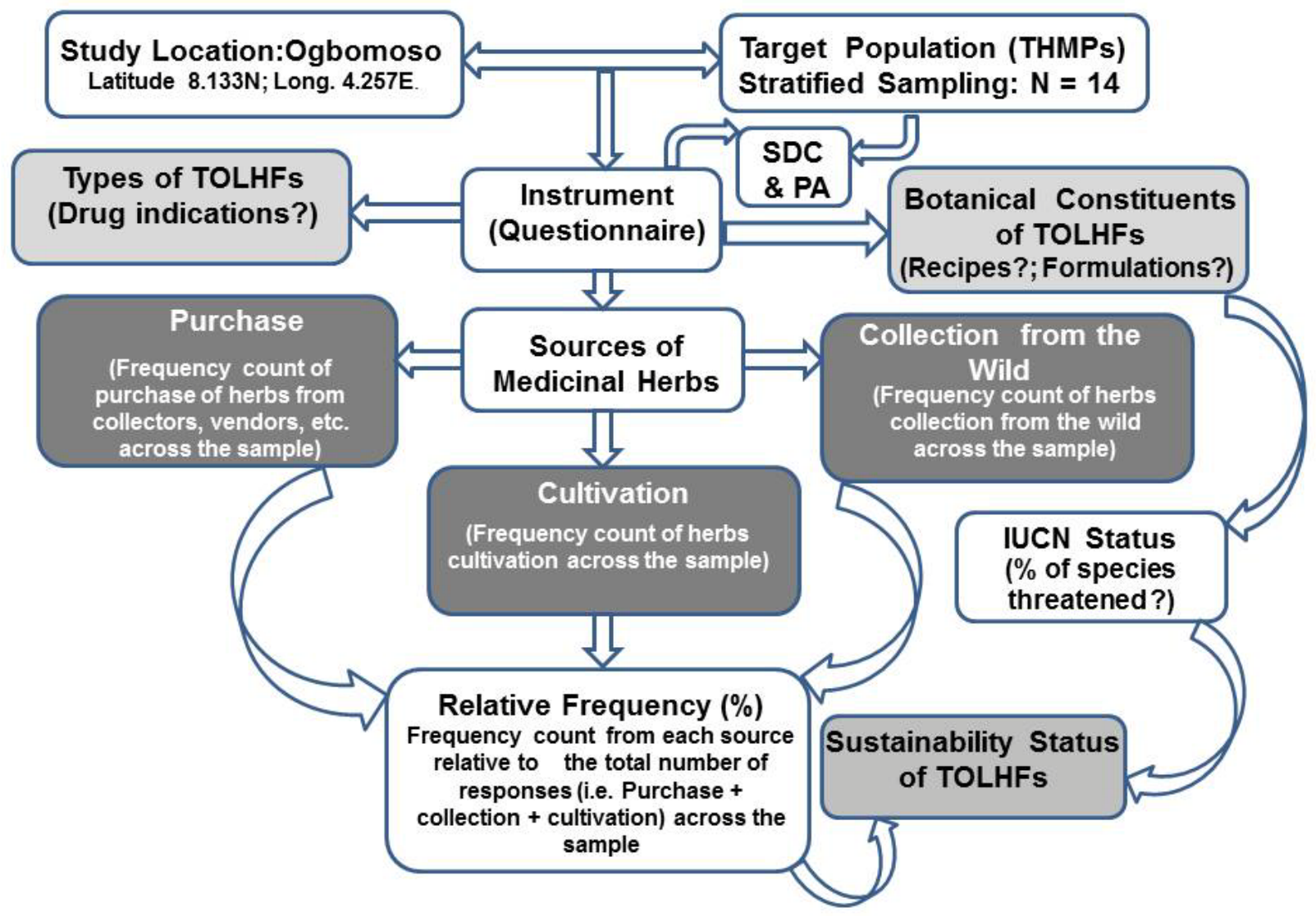

Figure 1: Summary of the methodology adopted towards achieving the three main objectives of the study (i.e. lightshaded boxes), and documenting the relative sources of medicinal herbs for TOLHFs in Ogbomoso, Nigeria (i.e. dark-shaded boxes). THMPs, traditional herbal medical practitioners; TOLHFs, traditional oral liquid herbal formulations; SDC, socio-demographic characteristics of THMPS; PA, professional activities; IUCN, International Union for conservation of Nature.

The 14 THMPs were assigned anonymity codes $A, B, C, D$, etc to $N$, while their products were labeled, each according to its indications (i.e. the health condition that the drug treats). To do this, each health condition was first given a short code of five alphabets, which was then used as a hyphenated prefix to the anonymity code of its manufacturer, such as YELLO-D (i.e. drug for yellow fever produced by healer D), PILESC (i.e. drug for piles from healer $\mathrm{C}$ ) and HIGBP-B (i.e. remedy for high blood pressure from healer $\mathrm{B}$ ) (see Table 2).

\section{Results}

a) Socio-demographic characteristics and professional activities of the traditional herbal medical practitioners

As recorded in Table1, thirteen (i.e. $76.5 \%$ ) of the 17 THMPs initially recruited to participate in the study were men and 4 (i.e.23.4\%) were women; 10 of them (about 59\%) were over 50 years of age. The majority of the healers (70.6\%) had only primary and/ or secondary education, but up to $65 \%$ of them had practiced in the profession for more than 30 years. Historically, majority (88\%) of these people came into the profession by descent, being their family trade, while few others either combined some form of training with this option or depended on their natural gifts or talents to become traditional healers. The THMPs ventured into updating their knowledge of medical practice through a wide range of choices, such as by intuition (35.3\%), attendance at health talks or meetings (11.8\%) and electronic media (about 6\%), while $47 \%$ of them adopted various forms of a combination of these and other choices (Table 1). Fourteen of the initially recruited 17 THMPs were involved in the production, sale and application of TOLHFs against 14 different types of health conditions including maintenance of general body homeostasis and the management of some dreaded diseases such as diabetes, high blood pressure, typhoid and yellow fever. All of the 14 THMPs produced oral liquid herbal formulations for malaria therapy; about $93 \%$ for piles; $86 \%$ for typhoid; $64 \%$ for blood enricher and 57\% for blood purifying drugs (Table 2). 
b) Medicinal herbs enumerated by the traditional herbal medical practitioners in Ogbomoso as recipes for oral liquid herbal formulations

A total of 57 medicinal plant species from 34 angiosperm families were listed by the THMPs as constituents of TOLHFs in Ogbomoso, Nigeria. Plants of the families Fabaceae, Euphorbiaceae, Amaryllidaceae and Meliaceae were most widely used, followed by those of Anacardiaceae,Annonaceae, Apocynaceae, Combretaceae, Cucurbitaceae, Poaceae, Rutaceae, Sapotaceae, Solanaceae, Sterculiaceae and Zingiberaceae. Members of the other 19 families were seldom used by the THMPs (Tables 3-13). The plant parts used as herbs include fruits, seeds, leaves, stem barks, flowers, roots and rhizomes, and six categories of TOLHFs were being produced, namely: decoctions, infusions, syrups, juices, tinctures and cold infuse drugs. A total of 71 recipes were being formulated, with details of the procedure, processes and products as presented in Figure 2.

c) Sources and conservation status of the raw material herbs for producing traditional oral liquid herbal formulations in Ogbomoso

Information obtained from the THMPs indicated the sources of raw material herbs available to them in relative terms as purchased from herbal markets and suppliers (38.7\%),

Table 1: Information about the traditional herbal healers who participated in the study

\begin{tabular}{|c|c|c|c|}
\hline \multirow[t]{2}{*}{ Variable } & \multicolumn{3}{|c|}{ Number of participants } \\
\hline & Male & Female & Total $(\mathrm{N}=17)$ \\
\hline \multicolumn{4}{|c|}{ Age (years) } \\
\hline $31-40$ & 4 & 0 & 4 \\
\hline $41-50$ & 2 & 1 & 3 \\
\hline$>50$ & 7 & 3 & 10 \\
\hline \multicolumn{4}{|c|}{ Formal Education } \\
\hline None & 0 & 2 & 2 \\
\hline Primary & 7 & 1 & 8 \\
\hline Secondary & 3 & 1 & 4 \\
\hline OND/NCE & 1 & 1 & 2 \\
\hline HND/Degree & 1 & 0 & 1 \\
\hline \multicolumn{4}{|c|}{ Experience (years) } \\
\hline$<10$ & 2 & 0 & 2 \\
\hline $10-20$ & 1 & 1 & 2 \\
\hline $21-30$ & 1 & 1 & 2 \\
\hline$>30$ & 9 & 2 & 11 \\
\hline \multicolumn{4}{|c|}{ Professional history } \\
\hline By descent & 11 & 4 & 15 \\
\hline By training & 0 & 0 & 0 \\
\hline $\begin{array}{l}\text { Both by descent and } \\
\text { training }\end{array}$ & 1 & 0 & 1 \\
\hline Others* & 1 & 0 & 1 \\
\hline \multicolumn{4}{|c|}{$\begin{array}{c}\text { Manufacturer of } \\
\text { Liquid herbal formulations (TOLHFs) }\end{array}$} \\
\hline Yes** & 11 & 3 & 14 \\
\hline No & 2 & 1 & 3 \\
\hline \multicolumn{4}{|c|}{$\begin{array}{l}\text { Update of knowledge } \\
\text { in medical practice }\end{array}$} \\
\hline By intuition $(A)$ & 5 & 1 & 6 \\
\hline $\begin{array}{l}\text { Attendance of meetings or } \\
\text { health talks }(B)\end{array}$ & 2 & 0 & 2 \\
\hline Electronic media $(\mathrm{C})$ & 1 & 0 & 1 \\
\hline Internet (D) & 0 & 0 & 0 \\
\hline$A$ and $B$ & 2 & 3 & 5 \\
\hline$A, B$ and $C$ & 1 & 0 & 1 \\
\hline $\mathrm{A}, \mathrm{B}, \mathrm{C}$ and $\mathrm{D}$ & 2 & 0 & 2 \\
\hline
\end{tabular}

OND, Ordinary National Diploma; NCE, Nigeria Certificate in Education; HND, Higher National Diploma.

*Talent from God; ** of the 17 herbal healers 14 produced liquid herbal formulations for oral use and their residential homes doubled as factories, with none of them having evidence of registration of their products with National Food and Drug Administration and Control. 
Table 2: List of health conditions indicated for traditional oral liquid herbal formulations manufactured and marketed in Ogbomoso, Nigeria

\begin{tabular}{|c|c|c|c|c|}
\hline Number & $\begin{array}{l}\text { Health Condition or } \\
\text { type of liquid herbal } \\
\text { formulation }\end{array}$ & $\begin{array}{l}\text { Local name of } \\
\text { health condition }\end{array}$ & $\begin{array}{l}\text { Number of } \\
\text { manufacturers } \\
(\mathrm{N}=14)\end{array}$ & $\begin{array}{l}\text { Types and Number of TOLHFs with } \\
\text { recipe information }\end{array}$ \\
\hline 1 & $\begin{array}{l}\text { Arthritis and rheumatism } \\
\text { (ARTRH) }\end{array}$ & Làkúègbé & 1 & IRNA \\
\hline 2 & $\begin{array}{l}\text { Back and/ waist pain } \\
\text { (BAWAP) }\end{array}$ & Èyìn dídùn & 1 & Decoction (1) \\
\hline 3 & $\begin{array}{l}\text { Blood enricher/enhancer } \\
\text { (BLENH) }\end{array}$ & Atún èjè se & 9 & Decoction (8); IRNA (1) \\
\hline 4 & $\begin{array}{ll}\text { Blood } & \text { purifier/thinner } \\
\text { (BLPUR) }\end{array}$ & Apa kòkòrò inú èjè & 8 & Syrup (2); decoction (3); infusion (1); IRNA (2) \\
\hline 5 & Body fatigue (BOFAT) & Ara wíwó & 2 & IRNA \\
\hline 6 & Convulsion (CONVU) & Gìrì omodé & 3 & Decoction (3) \\
\hline 7 & Diabetes (DIABE) & ìtò-súgà & 1 & IRNA \\
\hline 8 & Gonorrhea ( GONOR) & Àtòsí & 5 & Decoction (3); IRNA (2) \\
\hline 9 & $\begin{array}{l}\text { High blood pressure } \\
(\mathrm{HIGBP})\end{array}$ & Ejè ríru & 8 & $\begin{array}{l}\text { Decoction (5); infusion (1); infusion or tincture } \\
\text { (1); IRNA (1) }\end{array}$ \\
\hline 10 & $\begin{array}{l}\text { Jaundice/anaemia } \\
\text { (JAUND) }\end{array}$ & Afa èjè s'ára & 5 & $\begin{array}{l}\text { Decoction (3); decoction or tincture (1); IRNA } \\
\text { (1) }\end{array}$ \\
\hline 11 & Malaria fever (MALAR) & Ibà & 14 & Decoction (9); infusion (5) \\
\hline 12 & Piles (PILES) & Jèdíjèdí & 13 & $\begin{array}{l}\text { Decoction (5); decoction or tincture (2); } \\
\text { infusion (1); infusion or tincture (3); juice (1); } \\
\text { IRNA (1) }\end{array}$ \\
\hline 13 & Typhoid (TYPHO) & Ibà jèdòjèdò & 12 & $\begin{array}{l}\text { Decoction (10); infusion or tincture (1); juice } \\
\text { (1) }\end{array}$ \\
\hline 14 & Yellow fever (YELLO) & Ibà pónjú-póntò & 1 & Decoction (1) \\
\hline
\end{tabular}

IRNA, information on recipe not available

collection from the wild vegetation (35.5\%), and cultivation of some of the herbs for use (25.8\%). Furthermore, a scrutiny of the list of the plants against the IUCN red list of threatened plants revealed that only six of the 57 plant species have been evaluated for their conservation status and population dynamics (IUCN, 2017). From these six, three species are categorised as threatened, namely Garcinia kola(Vulnerable), Khaya senegalensis (Vulnerable) and Jatropha curcas (Endangered), constituting only $5.3 \%$ of all the plant species involved in the manufacturing of TOLHFs in the study area. The status of the other three species (i.e. Ceiba pentadra, Ficus exasperta and Khaya senegalensis) is of 'Least Concern' category.

Table 3: Names of plants and their parts used for the formulation of traditional oral liquid herbal drugs for the treatment of back and waist pain in Ogbomoso, Nigeria

\begin{tabular}{|c|c|c|c|c|}
\hline & Plant Species & Family name & Local name & Part(s) used \\
\hline 1 & Parkia biglobosa (Jacq.) R. Br. Ex G. Don. & Fabaceae & İbá/igi igbá & Stem bark \\
\hline 2 & Bridelia ferruginea Benth. & Euphorbiaceae & Irà & Stem bark \\
\hline 3 & Boerhaavia diffusa L. & Nyctaginaceae & Etìponlá & Leaves \\
\hline
\end{tabular}

Herbal recipe for one liquid decoction: BAWAP-A (1,2,3); suffix alphabet indicates the manufacturer's anonymity code. BAWAP, back and waist pain. 
Table 4: Names of plants and their parts for the formulation of traditional oral liquid herbal drugs used as blood enricher or enhancer in Ogbomoso, Nigeria

\begin{tabular}{|c|l|c|c|c|}
\hline & \multicolumn{1}{|c|}{ Plant species name } & Family & Local name & Part(s) used \\
\hline 1 & $\begin{array}{l}\text { Parkia biglobosa (Jacq.) R. Br. Ex G. } \\
\text { Don. }\end{array}$ & Fabaceae & İgá & Stem bark \\
\hline 2 & Paullinia pinnata L. & Sapindaceae & Kàkànselà & Leaves \\
\hline 3 & Theobroma cacao & Sterculiaceae & Kòkó & Stem bark \\
\hline 4 & Harungana madagascariensis & Hypericaceae & Amùjè & Stem bark \\
\hline 5 & Maranthes polyandra Benth. & Chrysobalanaceae & Araligi ara & Stem bark \\
\hline 6 & Allium sativum L. & Amaryllidaceae & Aáyù & Bulb \\
\hline 7 & Piper guinense Schumach. & Piperaceae & lyèré & Fruits \\
\hline 8 & $\begin{array}{l}\text { Anogeissus leiocarpus (DC) Guill \& } \\
\text { Perr. }\end{array}$ & Combretaceae & Àyin & Stem bark \\
\hline 9 & Xylopia aethiopica (Dunel) A. Rich. & Annonaceae & Èrù & Fruits \\
\hline
\end{tabular}

Herbal Recipes for eight oral decoctions: BLENH-A (1 only); BLENH-C (2 + potash); BLENH-D (3,4,5,6); BLENH-E (3,4,5+ potash + cube sugar).; BLENCH-F (5,7 + potash); BLENCH-M (8,9 + potash); BLENCH-O (3,4,5+ potash); and BLENCH-P (3,4,6); suffix alphabets indicate the manufacturers' anonymity codes. BLENH, blood enricher.

Table 5: Names of plants and their parts for the formulation of traditional oral liquid herbal drugs used as blood purifying or thinning drug in Ogbomoso, Nigeria

\begin{tabular}{|c|c|c|c|c|}
\hline & Plant species name & Family & Local name & Part(s) used \\
\hline 1 & Tetrapleura tetraptera (Schumm. \& Thonn.) Taub. & Fabaceae & Àìndan & Fruits \\
\hline 2 & Garcinia kola Heckel & Clusiaceae & Orógbó & Seeds \\
\hline 3 & Cola acuminata (P. Beauv.) Schott \& Endl. & Sterculiaceae & Obì àbàtà & Seed \\
\hline 4 & Paullinia pinnata L. & Sapindaceae & Kàkànselà & Leaves \\
\hline 5 & Parkia biglobosa (Jacq.) R.Br ex G.Don & Fabaceae & İgbá & Stem bark \\
\hline 6 & Alstonia boonei De Wild. & Apocynaceae & Ahùn/wáwòn & Stem bark \\
\hline 7 & Anacardium occidentale L. & Anacardiaceae & kajú & Stem bark \\
\hline 8 & Ceiba pentadra (L.) Gaertn. & Malvaceae & Àràbà & Stem bark \\
\hline 9 & Daniellia oliveri (Rolfe) Hutch. \& Dalziel & Fabaceae & lyá & Stem bark \\
\hline 10 & Azadirachta indica A. Juss. & Meliaceae & Dógóyárò & Stem bark \\
\hline 11 & Anogeissus leiocarpus (DC) Guill \& Perr. & Combretaceae & Àyin & Stem bark \\
\hline 12 & A. leiocarpus (DC) Guill \& Perr. & Combretaceae & Àyin & Root \\
\hline 13 & Xylopia aethiopica (Dunel) A. Rich. & Annonaceae & Èrù & Fruits \\
\hline 14 & Eugenia aromaticum (L.) Merr. \& L.M. Perry & Myrtaceae & Kànnáfùrù & Fruits or flowers \\
\hline 15 & Khaya senegalensis A. Juss. & Meliaceae & Àgànó & Stem bark \\
\hline
\end{tabular}

Herbal recipes for six oral liquid drugs;syrup: $\operatorname{BLPUR-B}(1,2,3+$ honey); $B L P U R-Q(1,2,3,6+$ honey); decoctions: BLPUR-C (4 + potash); BLPUR-E (5,6,7,8,9,10); BLPUR-O (5,6,8,15); infusion: BLPUR-M $(11,12,13,14) ;$; suffix alphabets indicate the manufacturers' anonymity codes.BLPUR, blood puritying or thinning drug. 
Table 6: Names of plants and their parts used for the formulation of traditional oral liquid herbal drugs for the treatment of convulsion in Ogbomoso, Nigeria

\begin{tabular}{|c|c|c|c|c|}
\hline & Plant Species name & Family & Local name & Part(s) used \\
\hline 1 & Parkia biglobosa (Jacq.) R.Br ex G.Don & Fabaceae & İgbá & Stem bark \\
\hline 2 & Daniellia oliveri (Rolfe) Hutch. \& Dalziel & Fabaceae & lyá & Stem bark \\
\hline 3 & Nicotiana tabacum L. & Solanaceae & Tábà & Fresh leaves \\
\hline 4 & Jatropha curcas L. & Euphorbiaceae & Làpálàpá & Leaves \\
\hline 5 & Crinum jagus (J. Thomps.) & Amaryllidaceae & Ògèdè-odò & Corm \\
\hline
\end{tabular}

Herbal recipes for three decoctions: CONVU-A (1,2); CONVU-B (3, $4+$ local table salt substitute 'obu-otoyo'); and CONVU-C (5 only); suffix alphabets indicate the manufacturers' anonymity codes. CONVU, convulsion.

Table 7: Names of plants and their parts used for the formulation of traditional oral liquid herbal drugs for the treatment of gonorrhoea in Ogbomoso, Nigeria

\begin{tabular}{|c|l|c|c|c|}
\hline & \multicolumn{1}{|c|}{ Plant species name } & Family & Local name & Part(s) used \\
\hline 1 & Citrullus colocynthis (L.) Schrad. & Cucurbitaceae & Bàrà/Ėgúsí & Fresh fruit \\
\hline 2 & Adenopus breviflorus Benth. & Cucurbitaceae & Tàgîrì & Fruit \\
\hline 3 & Capsicum frutescens L. & Solanaceae & Ata wéwé & Fruits \\
\hline 4 & Gladiolus psittacinus Hook & Iridaceae & Bákà & Bulb or leaf base \\
\hline 5 & Anthocleista djalonensis A. Chev. & Gentianaceae & Sápó & Stem bark \\
\hline 6 & Alstonia boonei De Wild. & Apocynaceae & Ahùn (wáwòn) & Stem bark \\
\hline 7 & Securidaca longepedunculata Fresen & Polygalaceae & İpèta & Root \\
\hline
\end{tabular}

Herbal recipes for three decoctions: GONOR-A (1 only); GONOR-E (1,2,3, 4); and GONOR-M

$(1,5,6,7)$; suffix alphabets indicate the manufacturers' anonymity codes. GONOR, gonorrhea.

Table 8: Names of plants and their parts used for the formulation of traditional oral liquid herbal drugs for the treatment or management of high blood pressure in Ogbomoso, Nigeria

\begin{tabular}{|c|l|c|c|c|}
\hline Number & \multicolumn{1}{|c|}{ Plant Species name } & Family & Local name & Part(s) used \\
\hline 1 & $\begin{array}{l}\text { Parkia biglobosa (Jacq.) R.Br } \\
\text { ex G.Don }\end{array}$ & Fabaceae & İgbá & Leaves \\
\hline 2 & Vernonia amygdalina Del. & Asteraceae & Ewúro & Leaves \\
\hline 3 & Ficus exasperata Vahl. & Moraceae & Ipín buds \\
or juvenile leaves
\end{tabular}

Herbal recipes for seven liquid drugs : Decoctions: HIGBP-B (1 only); HIGBP-D(3 only); HIGBP-E (4,5,6,7,8); HIGBP-N (12,13,14+ table salt); HIGBP-Q (1,15); infusion: HIGBP-C (2 only); infusion or tincture: $\operatorname{HIGBP-M}(9,10,11)$; suffix alphabets indicate the manufacturers' anonymity codes. HIGBP, high blood pressure. 
Table 9: Names of plants and their parts used for the formulation of traditional oral liquid herbal drugs for the treatment jaundice or anaemia in Ogbomoso, Nigeria

\begin{tabular}{|c|c|c|c|c|}
\hline Number & Plant Species name & Family & Local name & Part(s) used \\
\hline 1 & Parkia biglobosa (Jacq.) R.Br ex G.Don & Fabaceae & İgbá & Stem bark \\
\hline 2 & Paullinia pinnata L. & Sapindaceae & Kàkànselà & Leaves \\
\hline 3 & Senna alata (L.) Roxb. & Fabaceae & Àsùnwòn òyibó & Root, flower and leaves \\
\hline 4 & Xylopia aethiopica (Dunel) A. Rich. & Annonaceae & Ėrù & Fruits \\
\hline 5 & Olax subscorpioidea Oliv. & Olacaceae & Ifon & Root \\
\hline 6 & Alstonia boonei De Wild. & Apocynaceae & Ahùn/wáwòn & Stem bark \\
\hline 7 & Khaya senegalensis A. Juss. & Meliaceae & Àgànó & Stem bark \\
\hline 8 & Enantia chlorantha Oliv. & Annomaceae & Awopa/Dókítà igbó & Stem bark \\
\hline
\end{tabular}

Herbal recipes for four liquid drugs;Decoctions: JAUND-A (1 only); JAUND-C (2 + potash); JAUND-M (3 and 4); and decoction or tincture: JAUND-N (5,6,7,8); suffix alphabets indicate the manufacturers' anonymity codes.JAUND, jaundice.

Table 10: Names of plants and their parts used for the formulation of traditional oral liquid herbal drugs for the treatment of malaria fever in Ogbomoso, Nigeria

\begin{tabular}{|c|l|c|c|c|}
\hline Number & \multicolumn{1}{|c|}{ Plant Species name } & Family & Local name & Part(s) used \\
\hline 1 & Bridelia ferruginea Benth. & Euphorbiaceae & İrà & Stem bark \\
\hline 2 & Citrus aurantifolia (Christ.) Swingle & Rutaceae & Òrombó & Fruits (sliced) \\
\hline 3 & Mangifera indica L. & Anacardiaceae & Móngòrò & Stem bark \\
\hline 4 & Parkia biglobosa (Jacq.) R.Br ex G.Don & Fabaceae & İgbá & Stem bark \\
\hline 5 & Allium cepa L. & Amaryllidaceae & Àlùbósà & Bulb or leaf base \\
\hline 6 & Ananas comosus (L.) Merr. & Bromeliaceae & Òpe òyibó & Fruit (crushed) \\
\hline 7 & Alstonia boonei De Wild. & Apocynaceae & Ahùn/wáwòn & Stem bark \\
\hline 8 & Capsicum frutescens L. & Solanaceae & Ata wéwé/ata ìjòsì & Fruits \\
\hline 9 & Zingiber officinale Roscoe & Zingiberaceae & Atalè & Rhizome \\
\hline 10 & Khaya senegalensis A. Juss. & Meliaceae & Àgànó & Stem bark \\
\hline 11 & Anogeissus leiocarpus (DC) Guill \& Perr. & Combretaceae & Àyin & Stem bark \\
\hline 12 & Blighia sapida K. D. Koenig & Sapindaceae & Isin & Stem bark \\
\hline 13 & Enantia chlorantha Oliv. & Annomaceae & Awopa/Dókítà igbó & Stem bark \\
\hline 14 & Piper guinense Schumach. & Piperaceae & Iyèré & Fruits \\
\hline 15 & Terminalia glaucescens Planch. & Combretaceae & Idí-òdàn & Stem bark \\
\hline 16 & Sarcocephalus latifolius (Smith) Bruce & Rubiaceae & Ègbèsì & Stem bark \\
\hline 17 & Eugenia aromaticum (L.) Merr. \& L.M. Perry & Myrtaceae & Kànnáfùrù & Fruits/flower buds \\
\hline 18 & Aframomom melegueta K.Schum. & Zingiberaceae & Ataare & Seeds/fruit \\
\hline 19 & Parkia biglobosa (Jacq.) R.Br ex G.Don & Fabaceae & İgbá & Root bark \\
\hline 20 & Mangifera indica L. & Anacardiaceae & Móngòrò & Root bark \\
\hline
\end{tabular}

Herbal recipes for 14 liquid drugs; Decoctions: MALAR-A (1,2); MALAR-B (3,4,5); MALAR-C (6 + fermented maize water); MALAR-E (7, 10, 11, 12); MALAR-F (2, 13, 14 + fermented maize water); MALAR-I (7, 13, 15); MALAR-L (13 +fermented maize water); MALAR-M (7, 17 + table salt); MALAR-O (7, 9, 18); infusions: MALAR-D (7, 8, 9); MALAR-J (3, 5, 16); MALAR-N (7, 13, with cold water or 7-Up beverage drink); $\operatorname{MALAR-P}(7,8,9) ; \operatorname{MALAR-Q}(5,19,20)$; suffix alphabets indicate the manufacturers' anonymity codes. MALAR, malaria fever. 
Table 11: Names of plants and their parts used for the formulation of traditional oral liquid herbal drugs for the treatment of piles in Ogbomoso, Nigeria

\begin{tabular}{|c|l|c|c|c|}
\hline Number & \multicolumn{1}{|c|}{ Plant Species name } & Family & Local name & Part(s) used \\
\hline 1 & Senna accidentalis L. & Fabaceae & Réré abo & Root \\
\hline 2 & Senna tora (L.) Roxb. & Fabaceae & Réré ako & Root \\
\hline 3 & Allium cepa L. & Amaryllidaceae & Àlùbósà eléwé & Leaves \\
\hline 4 & $\begin{array}{l}\text { Alcohorneae laxiflora (Benth.) } \\
\text { Pax \& K. Hoffm. }\end{array}$ & Euphorbiaceae & ljàn & Leaves \\
\hline 5 & Euphorbia hirta L. & Euphorbiaceae & Emilè & leaves \\
\hline 6 & Anacardium occidentale L. & Anacardiaceae & Kajú & Stem bark \\
\hline 7 & Bridelia ferruginea Benth. & Euphorbiaceae & Irà & Stem bark \\
\hline 8 & Sarcocephalus latifolius (Smith) Bruce & Rubiaceae & Ègbès̀̀ & Stem bark \\
\hline 9 & Maranthes polyandra Benth. & Chrysobalanaceae & Araligi ara & Stem bark \\
\hline 10 & Anogeissus leiocarpus (DC) Guill \& Perr. & Combretaceae & Àyin & Stem bark \\
\hline 11 & Allium sativum L. & Amaryllidaceae & Aáyù & Bulb \\
\hline 12 & Ananas comosus (L.) Merr. & Bromeliaceae & Òpe òyibó & Fruit \\
\hline 13 & Citrullus colocynthis (L.) Schrad. & Cucurbitaceae & Bàrà/Ėgúsí & Fresh fruit \\
\hline 14 & Pseudocedrela kotchyii Harms & Meliaceae & Emi-gbègì & Stem bark \\
\hline 15 & Ancistrophylum secundiflorum L. & Areceae & Òkùùku & Stem bark \\
\hline 16 & Eugenia aromaticum (L.)Merr. \& L.M. Perry & Myrtaceae & Kànnáfùrù & Fruits \\
\hline 17 & Zingiber officinale Roscoe & Zingiberaceae & Atalè & Rhizome \\
\hline 18 & Khaya senegalensis A. Juss. & Meliaceae & Àgànó & Root bark \\
\hline 19 & Sorghum bicolor (L.) Moench & Poaceae & Okàa- bàbà & Leaf sheath \\
\hline 20 & Aristolochia ringens Vahl & Apocynaceae & Àbèrè & Fruit \\
\hline 21 & Huntaria umbellata K. Schum. & Akniaceae & Akogùn & Root \\
\hline
\end{tabular}

Herbal recipes for 12 oral liquid drugs; Decoctions: PILES-A (1,2 + potash); PILES-B (3, 4, 5 + fermented maize water); PILES-F (14, 15, 16, 17 + few tablets of edible camphor); PILES-L (18, 19, 20); PILES-O (7, 11, 16, 17); decoction or tincture: PILES-C (6, 7); PILES-D (7, 8, 9, 10, 11, 16, 17 + few tablets of edible camphor); infusion: PILES-N (3, 21); infusion or tincture: PILES-M (3, 16, 18, 20); PILES-P (7, 10, 11, 16, 17); PILES-Q (3, 4 + fermented maize water); juice (crush, squeeze and strain): PILES-E (12, 13 + potash); suffix alphabets indicate the manufacturers' anonymity codes. PILES, piles.

Table 12: Names of plants and their parts used for the formulation of traditional oral liquid herbal drugs for the treatment of typhoid in Ogbomoso, Nigeria

\begin{tabular}{|c|l|c|c|c|}
\hline Number & \multicolumn{1}{|c|}{ Plant Species name } & Family & Local name & Part(s) used \\
\hline 1 & Bridelia ferruginea Benth. & Euphorbiaceae & İrà & Stem bark \\
\hline 2 & Citrus aurantifolia (Christ.) Swingle & Rutaceae & Òrombó & Whole fruit \\
\hline 3 & Anogeissus leiocarpus (DC) Guill \& Perr. & Combretaceae & Àyin & Leaves \\
\hline 4 & Vernonia amygdalina Del. & Asteraceae & Ewúro & Root \\
\hline 5 & Xylopia aethiopica (Dunel) A. Rich. & Annonaceae & Ėù-alamo & Empty pods of fruits \\
\hline 6 & Aframomum melegueta K. Schum. & Zingiberaceae & Ataare & Seeds (7 or 9 pieces) ${ }^{\star}$ \\
\hline 7 & Capsicum frutescens L. & Solanaceae & Ata wéwé/ata ijòsì & Fruits (7 or 9 pieces)* \\
\hline 8 & Ananas comosus (L.) Merr. & Bromeliaceae & Òpe òyibó & Fruit $^{*}$ \\
\hline 9 & Saccharum officinarum L. & Poaceae & Irèké & Stem juice \\
\hline 10 & Gladiolus psittacinus Hook & Iridaceae & Bákà & Bulb \\
\hline 11 & Citrus aurantifolia (Christ.) Swingle & Rutaceae & Òrombó & Fruit juice \\
\hline
\end{tabular}




\begin{tabular}{|c|l|c|c|c|}
\hline 12 & Enantia chlorantha Oliv. & Annomaceae & $\begin{array}{c}\text { Awopa/Dókítà } \\
\text { igbó }\end{array}$ & Stem bark \\
\hline 13 & Alstonia boonei De Wild. & Apocynaceae & Ahùn/wáwòn & Stem bark \\
\hline 14 & Terminalia glaucescens planch. & Combretaceae & Ídi-òdàn & Stem bark \\
\hline 15 & Khaya senegalensis A. Juss. & Aeliaceae & Àgànó & Stem bark \\
\hline 16 & Mangifera indica L. & Zingiberaceae & Aóngòrò & Stem bark \\
\hline 17 & Zingiber officinale Roscoe & Rutaceae & Àta & Root \\
\hline 18 & $\begin{array}{l}\text { Zanthoxylum zanthoxyloides (Lam.) } \\
\text { Zepern. \& Timler }\end{array}$ & Amaryllidaceae & Àlùbósà eléwé & Leaves \\
\hline 20 & Allium cepa L. & Annonaceae & Erù-alamo & Whole fruits \\
\hline 21 & Anogeissus leiocarpus (DC) Guill \& Perr. & Combretaceae & Àyin & Root \\
\hline 22 & Daniellia oliveri (Rolfe) hutch. \& Dalziel & Fabaceae & lyá & Root bark \\
\hline 23 & $\begin{array}{l}\text { Tetrapleura tetraptera (Schumm. \& } \\
\text { Thonn.) Taub. }\end{array}$ & Fabaceae & Àìndan & Root \\
\hline
\end{tabular}

Herbal recipes for 12 oral liquid drugs; Decoctions: TYPHO-A (1, 2); TYPHO-C (3, 4, 5); TYPHO-D (3, 5, 6, 7); TYPHO-I (12, 13, 14); TYPHO-J (15 only); TYPHO-L (16 only); TYPHO-N (14, 18, 19, 20); TYPHO-O (11, 21, 22, 23); TYPHO-P (12, 13, 14); TYPHOQ (15 + potash); infusion or tincture: TYPHO-M (17 + 7-Up beverage drink + potash); juice (crush, squeeze and strain): TYPHOE (5, 8, 9, 10, and 11); suffix alphabets indicate the manufacturers' anonymity codes. TYPHO, typhoid. *7 or 9 pieces for female or male user of the remedies respectively.

Table 13: Names of plants and their parts used for the formulation of traditional oral liquid herbal drugfor the treatment of yellow fever in Ogbomoso, Nigeria

\begin{tabular}{|c|c|c|c|c|}
\hline Number & Plant Species name & Family & Local name & Part(s) used \\
\hline 1 & Alstonia boonei De Wild. & Apocynaceae & Ahùn/wáwòn & Stem bark \\
\hline 2 & Elais guinensis Jacq. & Arecaceae & Ope & Stem bark \\
\hline 3 & Sorghum bicolor (L.) Moench & Poaceae & Okàa- bàbà & Leaf sheath \\
\hline
\end{tabular}

Herbal recipe for one oral herbal decoction: YELLO-D (1, 2, 3 +potash); suffix alphabet indicates the manufacturer's anonymity code. YELLO, yellow fever.

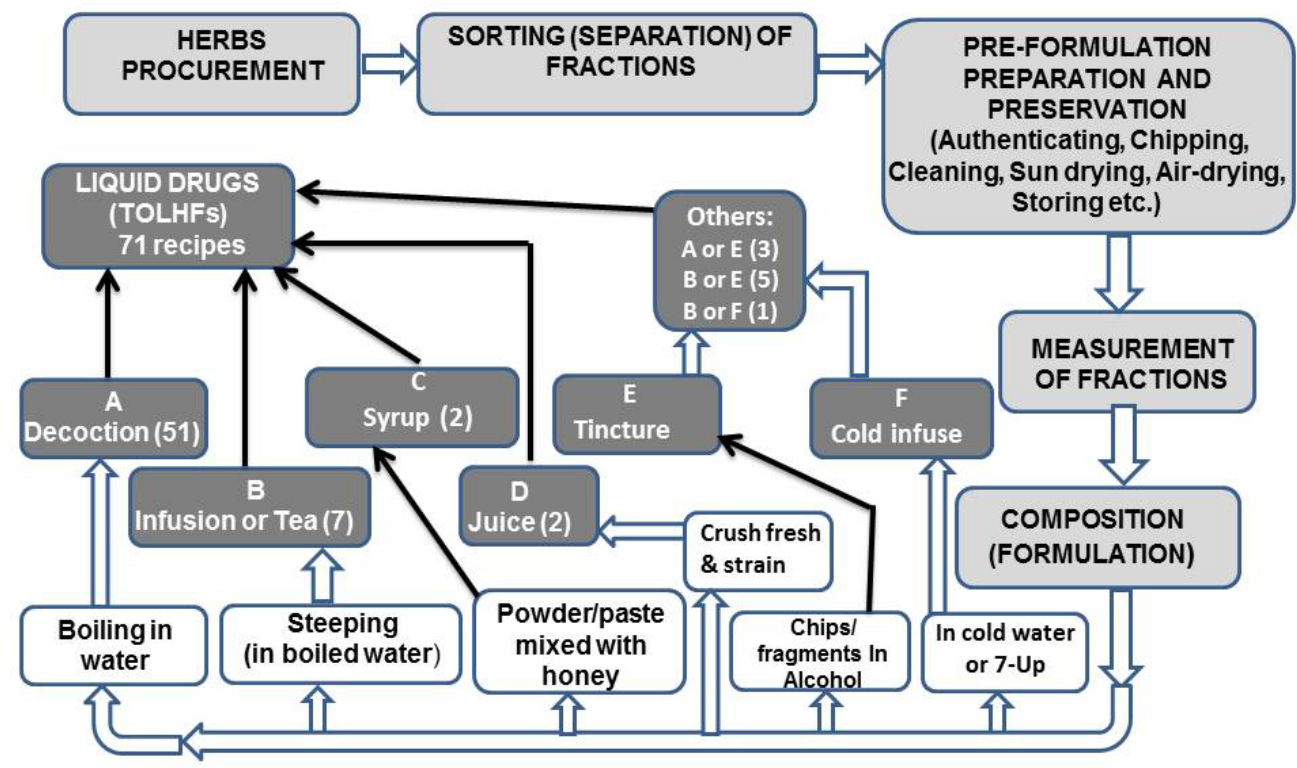

Figure 2: Documentation of the procedure (i.e. light-shaded boxes), process (i.e. un-shaded boxes), and products

(i.e. dark-shaded boxes) of TOHLFs in Ogbomoso, Nigeria. TOHLFS, traditional oral liquid herbal formulations 


\section{Disussion}

The presentation in Table 2 is indicative of prevalence of malaria, piles, typhoid and high blood pressure; and awareness of the necessity for blood forming and blood thinning drugs among the residents of Ogbomoso. However, ill health conditions such as arthritis, back or waist pain, diabetes and yellow fever appear to be relatively uncommon, or else, people suffering from these ailments did not seek healing or management from THMPs. There are reasons to believe that malaria is a major public health problem in Nigeria, including accounting for more cases and deaths than any other country in the world (United States Embassy in Nigeria, 2011; World Health Organisation, 2013). Predominance of antimalarial liquid drugs among the products from the traditional healers in the study area is a confirmation that the disease is prevalent in the southwestern parts of the country(Okunade, 2001).

Going by the principle of sustainable herbal medicine (Pesic, 2015), it is necessary to examine whether production of TOLHFs in Ogbomoso is sustainable, and if the exercise will not result in irreparable loss to the local vegetation. No doubt, the number of plant species being exploited for TOLHFsin the study area is on the high side (Tables 3-13), but our chief concern should be the sources of these raw materials. The results of this study revealed that about $39 \%$ of the medicinal herbs were sourced through purchase from herb vendors or suppliers. Even as a few of the purchased herbs were collections from outside Ogbomoso and its environs, a scrutiny of the lists in Tables 3-13 revealed that a substantial number of them were obtainable in the savanna woodland to which Ogbomoso ecologically belongs (Keay, 1989). For this reason, there is the probability that most of these plants were readily available in the past for free collection in the neighbourhoods, but now become articles for purchase due to urbanization and other related factors that have made then less accessible (Hsuch, 2009; Liu et al., 2015). It is therefore reasonable to believe that the natural flora of Ogbomoso has been largely impacted to the extent that only about $36 \%$ of the herbs are available for collection in the wild.

In order to truly ascertain the sustainability status of TOLHFs production in Ogbomoso, empirical data on the quantities of raw material herbs extracted annually for this purpose are required, and this information was not available to this study. But then, if it is assumed that the 51 of the plant species used for TOLHFs yet to be evaluated by the IUCN are not threatened, it is logical to infer from available data from this study, and information in the red list of IUCN that production of TOLHFs in Ogbomoso is sustainable. This position is strengthened by the facts that exploitation of plant seeds as in G. kola is a sustainable practice, and in fact, healthy to the plant (Rokaya et al., 2017); exploitation of $J$. curcas (i.e. the leaves) is also sustainable, and in addition, its cultivation is now being widely advocated for biodiesel production and other purposes in Nigeria (Fakayode et al., 2012; Raufu et al., 2014; Akogwu et al., 2018; Yahuza et al., 2020); and lastly, $K$. senegalensis, whose sustainable exploitation may be in doubt (i.e. the stem bark), is seldom employed $(7.1 \%)$ in manufacturing TOLHFs in the study area, and in such circumstance, a rotation system of collection can be adopted to reduce plants' sensitivity to harvesting and enhance their resilience (WHO, IUCN \& WWF, 1993). In addition, the efforts put up by the manufacturers of TOLHFs in cultivating about $26 \%$ of their raw material herbs are commendable, but there is room for improvement(Schippmannet al., 2002).

\section{Conclusion and Recommendation}

Seventy-one TOLHFs manufactured in Ogbomoso, Nigeria fell into five categories of remedies namely decoction (51), infusion or tea (7), syrup (2), juice (2), and others (9), which are indicated for the treatment of 14 different kinds of health conditions including malaria, piles and typhoid, and in the management of such dreaded diseases as high blood pressure, yellow fever, and diabetes. Herbs extracted from 57 plant species in 34 angiosperm families are used to produce these drugs, but the practice is adjudged sustainable with minimal injury on the neighbouring flora if sustainable harvesting can be encouraged or enforced alongside medicinal plants cultivation.

\section{ACKNOWLEDGEMENT}

The authors are grateful to the traditional healers in Ogbomoso and environs who offered to participate in the study.

\section{Competing interests}

The authors declare that they have no financial or personal relationships which may have inappropriately influenced them in writing this article.

\section{References Références Referencias}

1. ABFR \& Co. (1996). Chronology of Nigerian decrees, ABFR \& Co. Law Office, Onikan, Lagos, viewed 01 August 2018, from http://www.abfr\&co.com/1992 n.htm.

2. Akogwu RD, Aguoru CU, Ikpa F, Ogbonna I and Olasan JO (2018).Suitability of Jatrophacurcas L. as Source of Oil and Biodiesel Production in Benue State in Nigeria. Available: D0I: 10.4172/2157-7463. 1000378

3. Bauer, R. (1998). 'Quality criteria and standardization of phytopharmaceuticals: Can acceptable drug standards be achieved?',Drug 
Information Journal 32, 101-110. https://doi.org/ 10.1177/009286159803200114

4. Chen, S., Yu, H., Luo, H., Wu, Q., Li, C. and Steinmetz, A. (2016). 'Conservation and sustainable use of medicinal plants: Problems, progress and prospects', Chinese Medicine 11, 37. https://doi.org /10.1186/s13020-016-0108-7

5. Fakayode, S. B., Belewu, M.A, Muhammed, N.O, Adekola, O.F, Adebayo, G.B, Ameen, O.M, Raji, S. A., Ji-moh, A. A, and Olaniyan, A.M. (2012). Prospective JatrophaCurcas based Firms in Nigeria. How Viable? Proceedings of the 8th Congress of Africa Farm management Association(AFMA), Theme: "Repositioning African Agriculture by Enhancing Productivity, Market Access, Policy Dialogue and Adapting to Climate Change", MOI university Press, pp191-212.

6. Fatokun, O. (2020). Fostering local production of essential medicines in Nigeria. Bulletin of World Health Organization 98:507-508. doi: http:// dx.doi.org/10.2471/BLT.19.249508.

7. High Commission of India in Nigeria (2020).A study on the pharma and alternative medicine industries in Nigeria. High Commission of India, Abuja, Nigeria. http://hciabuja.gov.in/pdf/Nigeria Pharma Report as amended - Sent to client-May 20, 2020.pdf

8. Hsueh, D. (2009). 'New York City's metropolitan dome: Past and present $\mathrm{CO}_{2}$ concentration patterns from an urban to rural gradient', Unpublished M.A. thesis, Department of Ecology Evolution and Environmental Biology (E3B), Columbia University.

9. IUCN(2017). The IUCN red list of threatened species, International Union for Conservation of Nature, viewed 01 August 2018, from www.iucnredlist.org.

10. Kadam, P.V., Yadav, K.N., Patel, A.N., Navsare, V.S., Bhilwade, S.K. and Patil, M.J. (2012). 'Phytopharmacopoeial specifications of Garciniaindica fruit rinds', Pharmacognosy Journal 4(31), 2328. https://doi.org/10.5530/pj.2012.31.5

11. Keay, R.W.J., 1989, Trees of Nigeria, Oxford Science Publication, New York, p. 476. ISBN: 0-19-854560-6.

12. Lau, A.H., Woo, S. \& Koh, H. (2003). 'Analysis of adulterants in a traditional herbal medicinal product using liquid chromatography-mass spectroscopy', Journal of Pharmaceutical and Biomedical Analysis 31, 401-406. https://doi.org/10.1016/S0731-7085 (02)00637-4

13. Liu, Y. Wang, Y., Peng, J., Du, Y., Liu, X., Li, S.et al. (2015).'Correlations between urbanization and vegetation degradation across the world's metropolises using DMSP/OLS Nighttime Light Data', Remote Sensing 7, 2067-2088. https://doi. org/10.3390/rs70202067

14. Obu, R. N. (2015). Challenges facing traditional medicine in Ghana, Feature Article, Modern Ghana, viewed from www.modernghana.com/news/648038 /1/challenges-facing-traditional-medicine-ininghana.htm.

15. Ogunkunle, A. T. J. and Ashiru, S. B. (2011). Experience and perceptions of the residents of Ogbomoso land on the safety and efficacy of herbal medicines. Journal of Herbal Practice and Technology 1: 22-28.

16. Okunade, A.O. (2001). The underdevelopment of health care system in Nigeria, Faculty of Clinical Sciences and Dentistry, University of Ibadan, Vantage Publishers Limited, Ibadan, Nigeria.

17. Osunderu, O.A.(2009). 'Sustainable production of traditional medicines in Africa', in E.K. Yanful (ed.), Appropriate technologies for environmental protection in the developing world, pp. 43-51, Springer, Dordrecht.

18. Pastogi S. and Kaphle, K. (2011).Sustainable traditional medicine: Taking the inspirations from ancient veterinary Science. Evidence-Based Complementary and Alternative Medicine Volume 2011, Article ID 1514356 pages. Available: https:// doi.org/10.1093/ecam/nen071

19. Patwardhan, B., Warude, D., Pushpangadan, P. and Bhatt, N. (2005). 'Ayurveda and traditional Chinese medicine: A comparative overview', Evidence-Based Complementary and Alternative Medicine 4, 465473. https://doi.org/10.1093/ ecam/neh140

20. Pesic, M. (2015).Development of natural product drugs in a sustainable manner, Brief for GSDR 2015, viewed 03 August 2018, from https://sustainable development. un.org/.

21. Raufu, M.O., Olawuyi, S.O., Fayemo, K.A. and Akintola, R.O. (2014).Economics of biodiesel production from Jatrophacurcas $L$. in Nigeria.International Journal of Development and Sustainability 3(4): 908-916. Available: www.isdsnet. com/ijds

22. Schippmann, U., Leaman, D. J. and Cunningham, A. B. (2002). Impact of cultivation and gathering of medicinal plants on biodiversity: Global trends and issues. In: Biodiversity and the ecosystem approach in agriculture, forestry and fisheries. Satellite event on the occasion of the Ninth Regular Session of the Commission on Genetic Resources for Food and Agriculture. Rome, 12-13 October 2002. InterDepartmental Working Group on Biological Diversity for Food and Agriculture. Rome

23. United States Embassy in Nigeria (2011).Nigeria Malaria Fact Sheet, U.S. Embassy in Nigeria, FCT, Abuja, viewed 30 July 2018, from http://nigeria. embassy. gov; http://photos.state.gov/libraries/ 231771/public/December-Malaria Fact Sheet2.pdf.

24. World Health Organization (1998). Quality control methods for medicinal plant materials, World Health Organization, Geneva.

25. World Health Organization (2002).General guidelines for methodologies on research and 
evaluation of traditional medicine, World Health Organization, Geneva.

26. World Health Organization (2003). WHO guidelines on good agricultural and collection practices (GACP) for medicinal plants, WHO, Geneva.

27. World Health Organization, 2013, Malaria Fact sheets, World Health Organization, viewed 30 July 2018, from http://www.who.int/mediacentre/ factsheets/ fs094/en/.

28. WHO, IUCN \& WWF (1993). Guidelines on the conservation of medicinal plants. The international union for conservation of nature and natural resources (IUCN), Gland, Switzerland.

29. Yahuza, M. S., Gokcekus, H., Ahmad, S. M. and Yunusa, N. (2020). An overview study of Jatrophacurcas as a sustainable green energy and its economic impacts to local farmers in Kano State, Nigeria. Journal of Environmental Treatment Techniques 8 (3): 1060-1068. Available: http://www. jett.dormaj.com 